JOURNAL OF

HORTICULTURAL

SCIENCES
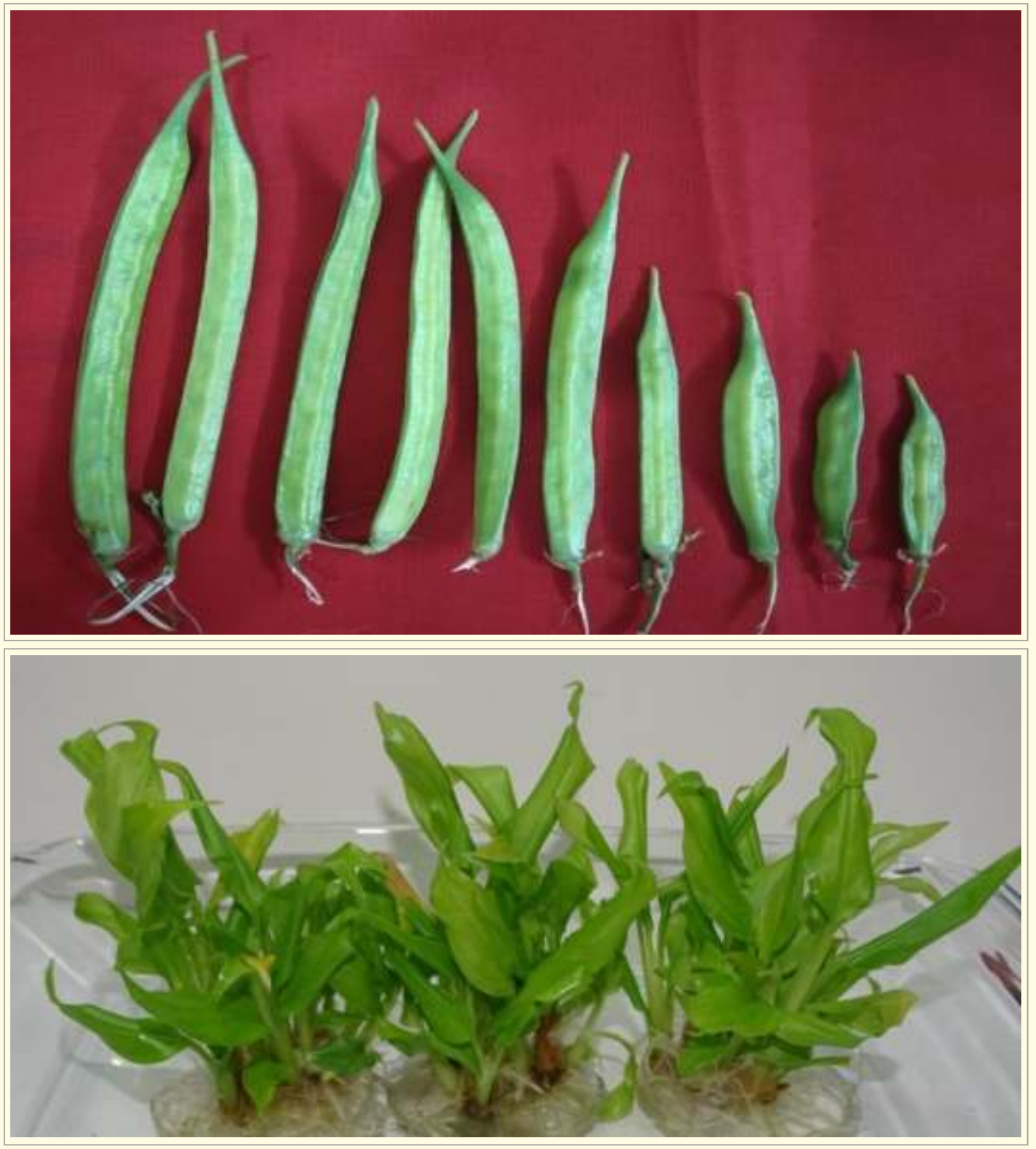

Society for Promotion of Horticulture

ICAR - Indian Institute of Horticultural Research, Bengaluru - 560089 


\section{JOURNAL OF HORTICULTURAL SCIENCES}

\section{ONTENTS}

\section{In this Issue}

\section{Review}

Moringa (Moringa oleifera L.): An underutilized and traditionally valued

tree holding remarkable potential

Jattan M., Kumari N., Raj Kumar, Kumar A., Rani B., Phogat D.S.,

Kumar, S. and Kumar, P.

\section{Original Research in Papers}

Characterization and evaluation of mountain sweet thorn

(Flacourtia montana J. Grah) collections

Tripathi P.C., Ganeshan S., Radhika V. and Shetti D.L.

Optimization of methodology for the extraction of polyphenolic compounds

with antioxidant potential and á-glucosidase inhibitory activity from jamun

(Syzygium cumini L.) seeds

Arivalagan M., Priyanka D.R. and Rekha A.

Genetic variability studies in amaranthus (Amaranthus spp.)

Agadi A.H., Kolakar S., Lakshmana D., Nadukeri S. and Hanumanthappa M.

Morpho-physiological parameters associated with chlorosis resistance to

iron deficiency and their effect on yield and related attributes in potato

(Solanum tuberosum L.)

Challam C., Dutt S., Sharma J., Raveendran M. and Sudhakar D.

Responses of different Okra (Abelmoschus esculentus) cultivars to water

deficit conditions

Ayub Q., Khan S.M., Hussain I., Naveed K., Ali S., Mehmood A., Khan M.J., Haq N.U., Shehzad Q.

Induced variability for yield and its attributing traits in cluster bean

[Cyamopsis tetragonoloba (L. ) Taub] through gamma irradiation

Lavanya H.N., Mishra S., Sood M., Aghora T.S., Anjanappa M., Rao V.K. and Reddy A.B.

In vitro multiplication protocol for Curcuma mangga : Studies on carbon,

Waman A.A., Bohra P., Karthika Devi R. and Pixy J. 
Effect of fungicide and essential oils amended wax coating on quality and shelf life of sweet orange (Citrus sinensis Osbeck)

Bhandari M., Bhandari N. and Dhital M.

Post-harvest quality and quantification of betalains, phenolic compounds and antioxidant activity in fruits of three cultivars of prickly pear

(Opuntia ficus-indica L. Mill)

Gonzalez F.P.H., Saucedo V.C., Guerra R.D., Suarez E.J., Soto H.R.M. Lopez J.A.,

Garcia C.E. and Hernandez R.G.

Soil microbial community dynamics as influenced by integrated nutrient management practices in sweet basil (Ocimum basilicum L.) cultivation Baraa AL-Mansour and D. Kalaivanan

Effect of spectral manipulation and seasonal variations on cut foliage production and quality of Philodendron (Philodendron 'Xanadu')

Sujatha A. Nair, Laxman R.H. and Sangama

\section{Short Communications}

Studies on mutagenic sensitivity of seeds of pummelo (Citrus maxima Merr.)

Sankaran M., Kalaivanan D. and Sunil Gowda D.C.

Isolation and characterization of microsatellite markers from

Garcinia indica and cross species amplification

Ravishankar K.V., Vasudeva R., Hemanth B., Nischita P., Sthapit B.R.,

Parthasarathy V.A. and Rao V.R. 
Original Research Paper

\title{
Soil microbial community dynamics as influenced by integrated nutrient management practices in sweet basil (Ocimum basilicum L.) cultivation
}

\author{
Baraa AL-Mansour ${ }^{* 1}$ and Kalaivanan D. ${ }^{2}$ \\ ${ }^{1}$ Ministry of Agriculture, Directory of Agriculture and Agrarian Reform, Lattakia, Syria \\ ${ }^{2}$ Division of Natural Resource Management, ICAR-Indian Institute of Horticultural Research, Bengaluru \\ *Corresponding author e-mail : baraaalmansour@yahoo.com.
}

\begin{abstract}
An experiment was conducted to study the effect of integrated nutrient management practices on the microbial community dynamics of soils under sweet basil (Ocimum basilicum L.) at ICAR - Indian Institute of Horticultural Research, Bengaluru during Kharif season of 2015 and 2016. There were nine treatments replicated thrice in randomized complete block design. The results indicated that integrated application of FYM $(10 \mathrm{t} / \mathrm{ha})+100 \%$ recommended $\mathbf{N}$ through $\mathrm{FYM}+$ bio-fertilizer i.e., $\mathrm{T}_{2}$ recorded the highest population of heterotrophic free-living $\mathrm{N}_{2}$ fixers $\left(40.66\right.$ and $\left.63.33 \mathrm{CFU} \times 10^{3} / \mathrm{g}\right)$, phosphate solubilizing bacteria (5.6 and 6.6 CFU $\left.\times 10^{3} / \mathrm{g}\right)$ and fungal $\left(6.4\right.$ and $\left.5.33 \mathrm{CFU} \times 10^{3} / \mathrm{g}\right)$ while $\mathrm{T}_{9}$ with application of NPK (160:80:80 $\mathrm{kg} / \mathrm{ha})+$ FYM (10 t/ha) recorded the highest population of actinomycetes $\left(29.93\right.$ and $\left.44.56 \mathrm{CFU} \times 10^{3} / \mathrm{g}\right)$ in soil during 2015 and 2016, respectively. Application of recommended dose of FYM (10 t/ha) in $T_{7}$ resulted in reduction in population of heterotrophic free-living $\mathrm{N}_{2}$ fixers $\left(26.13\right.$ and $\left.34 \mathrm{CFU} \times 10^{3} / \mathrm{g}\right)$ and actinomycetes (20 and $30.5 \mathrm{CFU} \times 10^{3} / \mathrm{g}$ ) whereas, the application of recommended dose of chemical fertilizer in $\mathrm{T}_{8}$ recorded the lowest population of phosphate solubilizing bacteria $\left(3.9 \mathrm{CFU} \times 10^{3} / \mathrm{g}\right)$ and fungal (3.6 and 2.5 CFU $\times 10^{3} / \mathrm{g}$ ) during 2015 and 2016, respectively. Highest organic carbon $(0.63$ and $0.66 \%)$ content in the post-harvest soil samples was recorded with application of NPK (160:80:80 kg /ha) + FYM (10 t/ha) while, the lowest organic carbon value $(0.52$ and $0.53 \%)$ was recorded in $T_{8}$ during 2015 and 2016, respectively. Application of recommended FYM (10 t/ha) along with recommended NPK $(160: 80: 80 \mathrm{~kg} / \mathrm{ha})$ in $T_{9}$ recorded maximum herbage yield in the main crop (41.59 and $38.31 \mathrm{t} / \mathrm{ha})$ and ratoon $(20.97$ and 17.77 t/ha) during 2015 and 2016, respectively. The results obtained from this study clearly demonstrated that integrated nutrient management can maximize soil microbial community dynamics which is considered as driving force behind regulating soil processes that support sustainable sweet basil cultivation.
\end{abstract}

Keywords : Chemical fertilizers, Bio-fertilizer, Farm yard manure, Soil microbial community and Sweet basil.

\section{INTRODUCTION}

Soil biota refers to the organisms both animals (fauna/ micro-fauna) and plants (flora/microflora) that determines overall quality, fertility and stability of the soils. Further, the process of soil formation, structural stabilization, nutrient cycling is largely regulated by these soil organisms. Hence, they are most important in achieving the soil sustainability. The fact is that soil contains a vast number and wide range of organisms which are important in the myriad of biochemical reactions and intricate biological processes that take place within the soil (Bajracharya, 2011). Koopmans and Smeding (2008) state that learning how to manage beneficial soil biological processes as the key step towards developing sustainable agricultural systems. Maintenance of soil fertility reflects positively on the crop yield (Mbonigaba, 2007). This can be achieved by practicing integrated nutrient management including application of organic manures that results in a general improvement in the soil organic matter (SOM) which represents the main reservoir of energy for 
microorganisms and nutrients supply for plants (ALmansour et al., 2019). Microorganisms such as bacteria, fungi and other micro fauna representatives are responsible for the energy and nutrients cycling (Bot and Benites, 2005). So it represents important component in the evaluation of soil quality and can be used as biological indicators for production systems (Franchini, 2007) and it has strong correlation with the soil organic matter, which in turn reflects in crop yield (Gundale, 2005). Increase in the microbial population have been linked to increase in soil carbon and ecological buffering capacity and in response to organic management, as well as various organic amendments application such as livestock manure (Ling et al., 2014). A 19-year long-term experiment conducted to evaluate the effects of fertilization regimes on soil organic carbon (SOC) dynamics indicated that the SOC content in the top $20 \mathrm{~cm}$ soil layer remained unchanged over time under the unfertilized control plot whereas it significantly increased under both organic, bio and NPK fertilizers and combined manure treatments (Yang et al., 2011).

Regular/recommended application of organic manures such as FYM that increase soil aggregation is therefore vital because most soils rely on aggregation of particles to maintain favorable conditions for soil microbial and faunal activity, plant growth and yield (Yu et al., 2012). An experiment was conducted to study the effect of FYM, bio-fertilizers, mineral NPK fertilization on vegetative growth, oil production and chemical composition of basil plant. The results obtained by (Zeinab, 2005) indicated that the application of FYM at high level (25t/ha) significantly increased the studied parameters compared with other fertilization including the control. The interaction between the main-plots (FYM treatments) and subplots (bio, and NPK treatments) had significant effect on the yield parameters.

The rise in agricultural systems studies concerning soil quality and microbial properties are a reflection of the importance of soil to the understanding of agricultural sustainability. How management practices impact the soil is fundamental in evaluating the sustainability of an agricultural system. More than just a substrate for supporting root structure, the soil has its own complexes ecosystem in which microorganisms are the dominant form of life and are responsible for performing functions vital to soil productivity. Sweet basil (Ocimum basilicum L.) belonging to the
Lamiaceae family, cultivated around the world (Baritaux et al., 1992) is considered as an important source for food and medicine (Palada et al., 2002). However, the studies on integrated nutrient management in basil are meager. Hence, the study was conducted with different combination of inorganic fertilizers, organic manure (FYM) and bio- fertilizer to find out their effect on dynamics of soil microbial population and organic carbon in sweet basil (Ocimum basilicum L.) cultivation.

\section{MATERIAL AND METHODS}

\section{Experimental location and treatment details}

Field experiments were conducted in a randomized complete block design with three replications in an experimental field of ICAR-Indian Institute of Horticultural Research (IIHR), Bangalore during the kharif season of 2015 and 2016. The experimental station is situated at an altitude of $890 \mathrm{~m}$ above mean sea level and $13^{\circ} 58^{\prime \prime}$ North latitude and $77^{\circ} 29^{\prime \prime}$ East longitudes. The nine treatments of the experiment consisted of different combinations of organic manure (FYM), bio-fertilizers and chemical fertilizers (NPK) : $\mathrm{T}_{1}$ - $(\mathrm{FYM}(10 \mathrm{t} / \mathrm{ha})+100 \%$ recommended $\mathrm{N}$ through FYM $), \mathrm{T}_{2}-(\mathrm{FYM}(10 \mathrm{t} / \mathrm{ha})+100 \%$ recommended $\mathrm{N}$ through FYM + Arka Microbial Consortium @ 5 $\mathrm{kg} / \mathrm{acre}), \mathrm{T}_{3}-(\mathrm{FYM}(10 \mathrm{t} / \mathrm{ha})+75 \%$ recommended $\mathrm{N}$ through FYM), $\mathrm{T}_{4}-(\mathrm{FYM}(10 \mathrm{t} / \mathrm{ha})+75 \%$ recommended $\mathrm{N}$ through $\mathrm{FYM}+$ Arka Microbial Consortium@5 kg/acre), T 5 - (FYM (10 t/ha) + $50 \%$ recommended $\mathrm{N}$ through $\mathrm{FYM}), \mathrm{T}_{6}-(\mathrm{FYM}(10$ $\mathrm{t} / \mathrm{ha})+50 \%$ recommended $\mathrm{N}$ through FYM + Arka Microbial Consortium @ 5 kg/acre), $\mathrm{T}_{7}$ (recommended FYM (10 t/ha) only), $\mathrm{T}_{8}$ (recommended NPK(160:80:80 kg/ha) only), and $\mathrm{T}_{9}$ - (recommended FYM (10 t/ha) + recommended NPK (160:80:80 kg/ha). Estimated N content of FYM used in this experiment was $0.64 \%$. Arka Microbial Consortium (AMC) is a carrier-based product which contains N Fixing, P \& Zn solubilizing and plant growth promoting microbes as a single formulation. After 15 days of transplanting, recommended dose of AMC @ $5 \mathrm{~kg} /$ acre was applied at $2 \mathrm{~cm}$ deep to individual plants in treatments T2, T4, T6 and immediately covered by soil. Similar method of application was followed for ratoon crop after harvest of main crop.

\section{Land preparation}

The land was brought to a fine tilth by ploughing and harrowing. The experimental site was divided 
into plots having dimensions of $4.8 \mathrm{~m}$ long and 4.0 $\mathrm{m}$ wide with the spacing of $40 \mathrm{~cm}$ between the plants and $60 \mathrm{~cm}$ between the rows. There was a space of 0.5 meter between plots and 0.5 meter between replications. Basil seeds were sown in two nursery beds of $6.0 \mathrm{~m}$ in length with $0.1 \mathrm{~m}$ in width and $10 \mathrm{~cm}$ height. Forty days old (40 days) healthy and uniformly rooted seedlings of sweet basil were transplanted to the field. Weeding was done manually and drip irrigation was given daily for half an hour during the early stages of the crop and subsequently irrigation was given depending on the soil moisture condition.

\section{Estimating the fresh herbage yield}

Five plants were randomly selected from each plot for recording the observations and the crop was harvested at full bloom stage before setting the seed. Fresh herbage harvested from each plot was weighed and converted to per hectare and expressed in tonnes $(\mathrm{t})$.

\section{Microbial population of the soil}

Microbial population of the soil under different treatments was enumerated by standard plate count technique. Total bacterial count in soil was determined by serial dilution method. For the study, initial soil samples prior to the start of the experiment and after harvest were collected from the surface layer $(0-15 \mathrm{~cm})$ according to different treatments with three replications. Exactly $5 \mathrm{gm}$ of soil sample was taken into $50 \mathrm{ml}$ of sterile distilled water and shaken for 15 minutes. A series of 9 fold dilutions were prepared and $0.1 \mathrm{ml}$ of each dilution was spread on media plates. To enumerate fungal, azotobacter, phosphate solubilising bacteria and actinomycetes population, potato dextrose agar (PDA), Jensen's media, Pikovskaya Agar and Kenknight media were used, respectively. After 35 days of incubation microbial population was counted following the spread plate technique and expressed as $\mathrm{CFU} \times 10^{3} / \mathrm{g}$ of soil.

\section{Organic carbon estimation (\%)}

The organic carbon content of the soil was estimated by Walkley and Black wet oxidation method as described by Jackson (1973).

\section{Statistical Analysis}

The data generated from the experiment were analyzed using SAS 9.3 version of the statistical package (SAS Institute Inc, 2011). Analysis of variance (ANOVA) was performed using SAS PROC ANOVA procedure. Means were separated using Fisher's protected least significant difference (LSD) test at a probability level of $\mathrm{p}<0.01$

\section{RESULTS AND DISCUSSION}

\section{Population of heterotrophic free-living $\mathrm{N}_{2}$ fixers}

The data in Table 1 indicated significant difference among the treatments with respect to population of heterotrophic free-living $\mathrm{N}_{2}$ fixers $\left(\mathrm{CFU} \times 10^{3} / \mathrm{g}\right.$ of soil). While, maximum population of the colonies in the soil after cropping (40.66 and $63.33 \mathrm{CFU}$ $\left.\times 10^{3} / \mathrm{g}\right)$ was recorded in $\mathrm{T}_{2}$ with application of FYM (10 t/ha) $+100 \%$ recommended $\mathrm{N}$ through FYM + Arka Microbial Consortium @ 5kg/acre during 2015 and 2016, respectively. Whereas, the treatment i.e. $\mathrm{T}_{7}$ recorded the lowest counts $(26.13$ and $34 \mathrm{CFU} \times 10^{3} / \mathrm{g}$ ) during first and second year, respectively. The addition of organic manure greatly influences the microbial populations which expected to cause changes in the organic matter content of soil that directly influenced microbial dynamics of soil (Deforest et al., 2012). Application of bio-fertilizer stimulates the native soil microorganisms and reactivates the biogeochemical cycles leading to increase in the organic material that significantly increases the bacterial populations. The results are on line with Watts et al., (2010), Krishnakumar et al. (2005) and Lalfakzuala et al., (2008).

\section{Population of phosphate solubilizing bacteria}

The data on the population of phosphate solubilizing bacteria ( $\mathrm{CFU} \times 10^{3} / \mathrm{g}$ of soil) after cropping given in Table 1 indicated that there was no significant difference between the treatments during first year (2015). The application of FYM (10 t/ha) + 100\% recommended $\mathrm{N}$ through FYM + Arka Microbial Consortium@5kg/acre i.e., $\mathrm{T}_{2}$ recorded the highest population of PSB $\left(5.6 \mathrm{CFU} \times 10^{3} / \mathrm{g}\right)$ while, the lowest PSB $\left(3 \mathrm{CFU} \times 10^{3} / \mathrm{g}\right)$ was recorded in $\mathrm{T}_{8}$. However, there were significant differences among the treatments in respect to population of 
phosphate solubilizing bacteria in the soil after cropping was observed during second year (2016). Similar to first year, application of FYM (10 t/ha) $+100 \%$ recommended $\mathrm{N}$ through $\mathrm{FYM}+$ Arka Microbial Consortium@5kg/acre recorded the highest population of PSB $\left(6.6 \mathrm{CFU} \times 10^{3} / \mathrm{g}\right)$ in soil while, the application of recommended dose of chemical fertilizer recorded the lowest population of PSB (3.9 $\left.\mathrm{CFU} \times 10^{3 /} \mathrm{g}\right)$.

Growth of $\mathrm{P}$ solubilizing microorganisms is generally accompanied by decrease in $\mathrm{pH}$ of the soil (Mishra, 1985). Reduction in $\mathrm{pH}$ due to application of FYM along with bio-fertilizer is a result of the production of organic acids which include citric, gluconic, fumaric, malic, oxalic, lactic, 2- ketogluconic, malonic acids etc. (Vassilev, 1996). Although chemical fertilization has resulted in increases in crop yield, this application was not sufficient in triggering a significant improvement in the soil microbial properties. Similar results were obtained by Wang et al., (2011). The addition of fertilizers enriched the soil microbial biomass and soil enzymes by enhancing the soil physicochemical properties and soil organic matter, especially through the addition of FYM. Root exudates augmented the soil microbes in general by the crop growth and that could explain the increase of soil population at harvest time comparing with the initial soil.

\section{Population of fungi}

Fungal population in the soil after cropping in two years of the experiment was affected significantly by the treatments involving different levels of organic manure with and without bio-fertilizers and inorganic fertilizers. As showed in Table 2 application of FYM $(10 \mathrm{t} / \mathrm{ha})+100 \%$ recommended $\mathrm{N}$ through FYM + Arka Microbial Consortium @ $5 \mathrm{~kg} /$ acre $\left(\mathrm{T}_{2}\right)$ recorded the maximum fungal population $\left(6.4\right.$ and $\left.5.33 \mathrm{CFU} \times 10^{3} / \mathrm{g}\right)$ in the soil while, the application of recommended dose of chemical fertilizer $\left(\mathrm{T}_{8}\right)$ recorded the lowest fungal population (3.6 and $2.5 \mathrm{CFU} \times 10^{3 /} \mathrm{g}$ ) in the soil after cropping in 2015 and 2016, respectively.

Microbial population size and community structure are sensitive to changes in chemical properties of the surrounding soil (Pansombat et al., 1997). Fungi constitute an essential component of biological characteristics in soil ecosystems. Organic carbon level in the soil and precipitation play pivotal role in fungal growth and sporulation. Greater microbial populations in FYM treated plots along with bio-fertilizer as compared to chemically amended plots due to enhancing the organic carbon in the soil. Similar kind of results was reported by Venkateswarlu and Srinivasa Rao, (2000). Application of farm yard manure can be viewed as an excellent way to recycle nutrients and provide a steady source of organic $\mathrm{C}$ to support the microbial community resulting in higher fungal populations compared to NPK- treated plots.

Lower fungal population in soil with application of chemical fertilizers alone is attributed to lack of organic amendment input. The microbial population dynamics is governed by interactions between plant type, climate, and management practice. So that, the low temperature that prevailed in the first season could have influenced the proliferation of fungi, which require low temperature for their growth; Song et al. (2007) indicated that difference in the establishment of field leads to alteration of microbial communities.

\section{Population of actinomycetes}

The data in Table 2 on actinomycetes population of the soil after cropping (CFU $\times 10^{3} / \mathrm{g}$ of soil) indicated significant differences between the treatments. The highest population of actinomycetes $\left(29.93\right.$ and $44.56 \mathrm{CFU} \times 10^{3} / \mathrm{g}$ of soil) was recorded in $\mathrm{T}_{9}$ with application of recommended NPK (160:80:80 kg/ha) + FYM (10 t/ha) during 2015 and 2016, respectively, while application of recommended dose of FYM (10 t/ ha) in $\mathrm{T}_{7}$ resulted in minimum population (20 and and $30.5 \mathrm{CFU} \times 10^{3 /} \mathrm{g}$ of soil) during 2015 and 2016 , respectively.

Actinomycetes are one of the predominant members of soil microbial communities and they have beneficial roles in soil nutrients cycling and agricultural productivity (Elliot and Lynch, 1995). Organic matter, salinity, relative moisture, temperature, $\mathrm{pH}$ and vegetation are important factors which control abundance of actinomycetes in soil (Mcarthy and Williams, 1992). The density of actinomycetes is opposite to the hydrogen ion concentration, that could justify increasing its population with application of NPK along with 
Soil microbes and integrated nutrient management in sweet basil

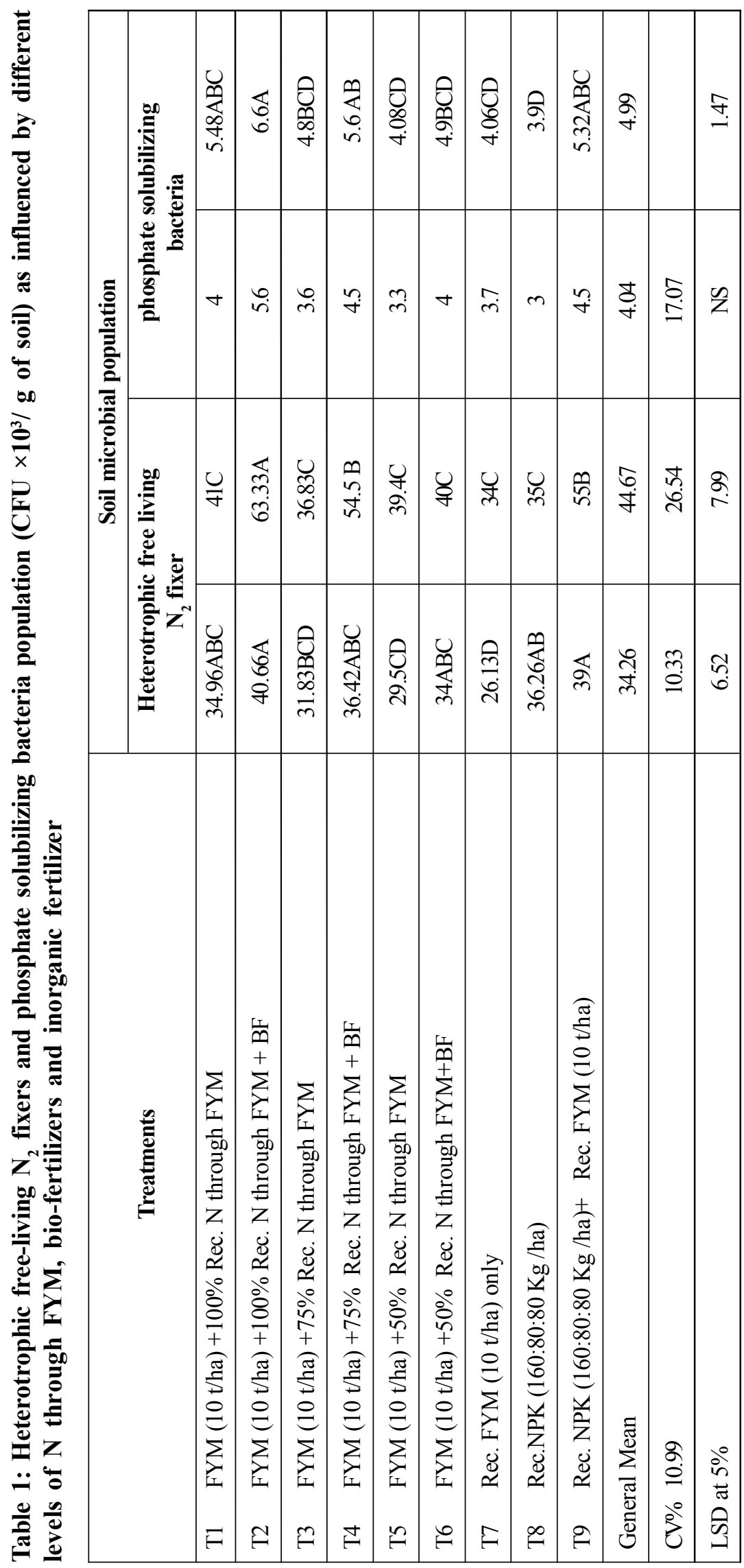




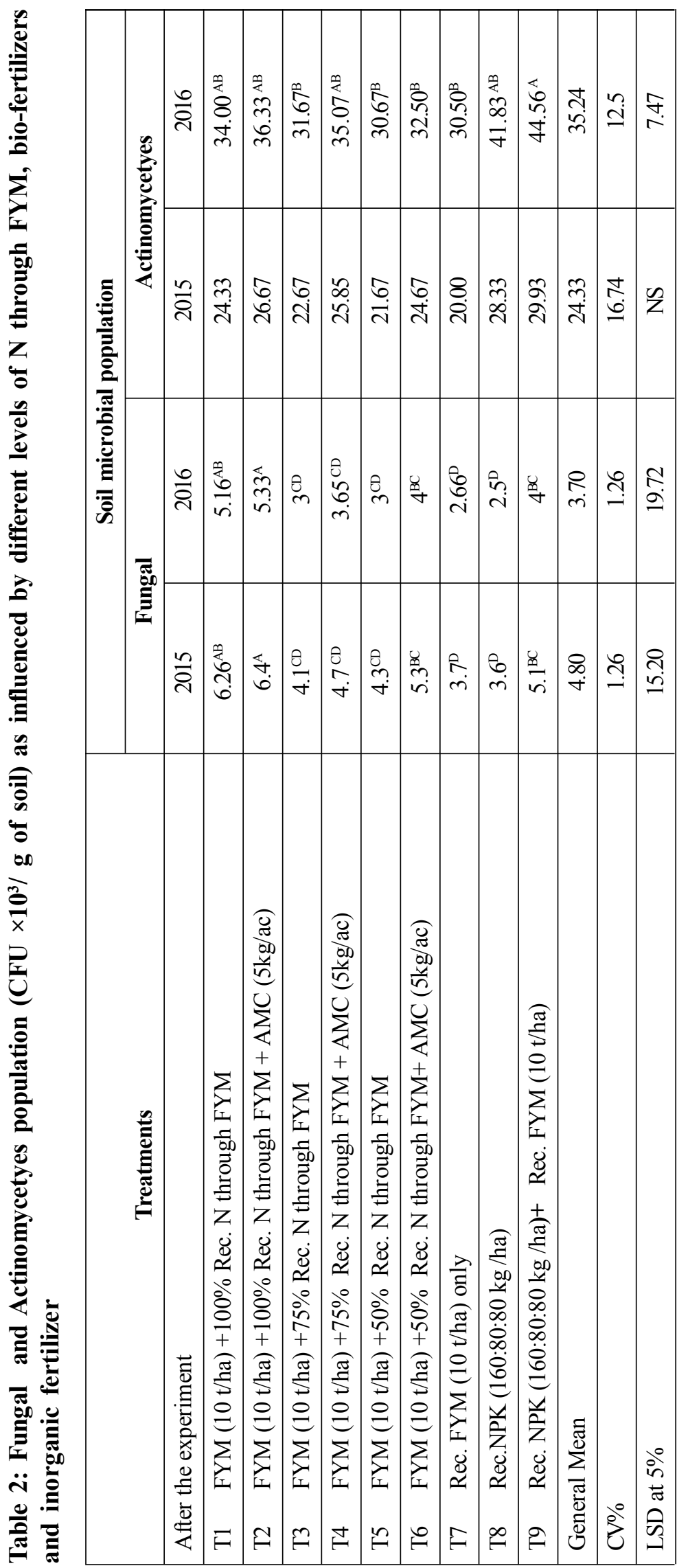


FYM (Alexander, 1977) While, increasing the colony's in the second season comparing to first one due to a relatively low level of moisture, this property of actinomycetes might be due to their sporulation capability under stress conditions (ElTarabily and Sivasithamparam, 2006).

\section{Organic carbon}

The treatments effect on organic carbon per cent in the soil are presented in Table 3. Application of FYM (10 t/ha) $+100 \%$ recommended $\mathrm{N}$ through FYM + Arka Microbial Consortium @ 5kg/acre i.e., $\mathrm{T}_{2}$ recorded the maximum organic carbon $(0.63$ and $0.66 \%$ ) in the post-harvest soil samples collected during 2015 and 2016, respectively. While, the minimum value $(0.52$ and $0.53 \%)$ was recorded in $\mathrm{T}_{8}$ with application the recommended dose of inorganic fertilizer (160:80:80 kg /ha) during 2015 and, 2016, respectively. Organic carbon per cent is fine indicators of soil quality which influence soil function in specific ways (e.g., immobilization-mineralization) and are much more sensitive to change in soil management practices (Saviozzi et al., 2001). The results showed the positive influence of higher level of $\mathrm{N}$ through FYM and bio-fertilizer in increasing the organic carbon content that could be because of the effect of FYM and bio-fertilizer in stimulation of soil microbial activity, therefore increasing the $\mathrm{C}$ output. Similar results were also found by Halvorson et al., (2002); Su et al., (2006) and Lou et al., (2011).

\section{Fresh herbage yield}

The fresh herbage yield of basil differed significantly between the treatments during two years of the experiment. It is evident from the Table 4 that the application of NPK (160:80:80 kg /ha) + FYM (10 t/ha) i.e., $\mathrm{T}_{9}$ recorded significantly the highest herbage yield in the main crop (41.59 and $38.31 \mathrm{t} / \mathrm{ha}$ ) and ratoon (20.97 and $17.77 \mathrm{at} / \mathrm{ha})$ during kharif 2015 and 2016, respectively. The lowest fresh herbage yield per hectare was recorded with recommended dose of FYM alone in the main crop (28.36 and $17.49 \mathrm{t} / \mathrm{ha})$ and in ratoon (12.59 and $8.93 \mathrm{t} / \mathrm{ha}$ ) during first and second year, respectively. Similar trend was also reflected in total herbage yield of basil. Application of NPK (160:80:80 kg /ha) + FYM (10 t/ha) i.e., $\mathrm{T}_{9}$ recorded significantly the highest total herbage yield (62.56 and 56.08) while, the lowest value (40.95 and 26.42 $\mathrm{t} / \mathrm{ha}$ ) was recorded in $\mathrm{T}_{7}$ during individual years.

Table 3: Organic carbon content (\%) in the soil as influenced by different levels of $\mathrm{N}$ through FYM, bio-fertilizers and inorganic fertilizer

\begin{tabular}{|c|c|c|c|}
\hline & Treatments & Org & $n(\%)$ \\
\hline Bef & re the experiment & & \\
\hline Aft & $r$ the experiment & 2015 & 2016 \\
\hline $\mathrm{T} 1$ & FYM (10 t/ha) $+100 \%$ Rec. N through FYM & $0.61^{\mathrm{AB}}$ & $0.65^{\mathrm{A}}$ \\
\hline $\mathrm{T} 2$ & FYM (10 t/ha) +100\% Rec. N through FYM + AMC (5kg/ac) & $0.63^{\mathrm{A}}$ & $0.66^{\mathrm{A}}$ \\
\hline $\mathrm{T} 3$ & FYM (10 t/ha) $+75 \%$ Rec. N through FYM & $0.58^{\mathrm{ABC}}$ & $0.62^{\mathrm{A}}$ \\
\hline $\mathrm{T} 4$ & FYM (10 t/ha) +75\% Rec. N through FYM + AMC (5kg/ac) & $0.61^{\mathrm{AB}}$ & $0.65^{\mathrm{A}}$ \\
\hline T5 & FYM (10 t/ha) $+50 \%$ Rec. N through FYM & $0.56^{\mathrm{ABC}}$ & $0.60^{\mathrm{AB}}$ \\
\hline T6 & FYM $(10 \mathrm{t} / \mathrm{ha})+50 \%$ Rec. N through FYM + AMC $(5 \mathrm{~kg} / \mathrm{ac})$ & $0.58^{\mathrm{ABC}}$ & $0.64^{\mathrm{A}}$ \\
\hline $\mathrm{T} 7$ & Rec. FYM (10 t/ha) only & $0.55^{\mathrm{ABC}}$ & $0.57^{\mathrm{ABC}}$ \\
\hline $\mathrm{T} 8$ & Rec.NPK (160:80:80 kg /ha) & 0.52 & $0.53^{\mathrm{C}}$ \\
\hline $\mathrm{T} 9$ & Rec. NPK (160:80:80 kg /ha)+ Rec. FYM (10 t/ha) & $0.54^{\mathrm{BC}}$ & $0.54^{\mathrm{BC}}$ \\
\hline Ger & ral Mean & 0.58 & 0.60 \\
\hline $\mathrm{CV}$ & & 5.09 & 6.13 \\
\hline LSI & at $5 \%$ & 0.02 & 0.03 \\
\hline
\end{tabular}




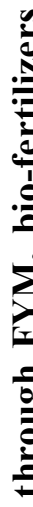

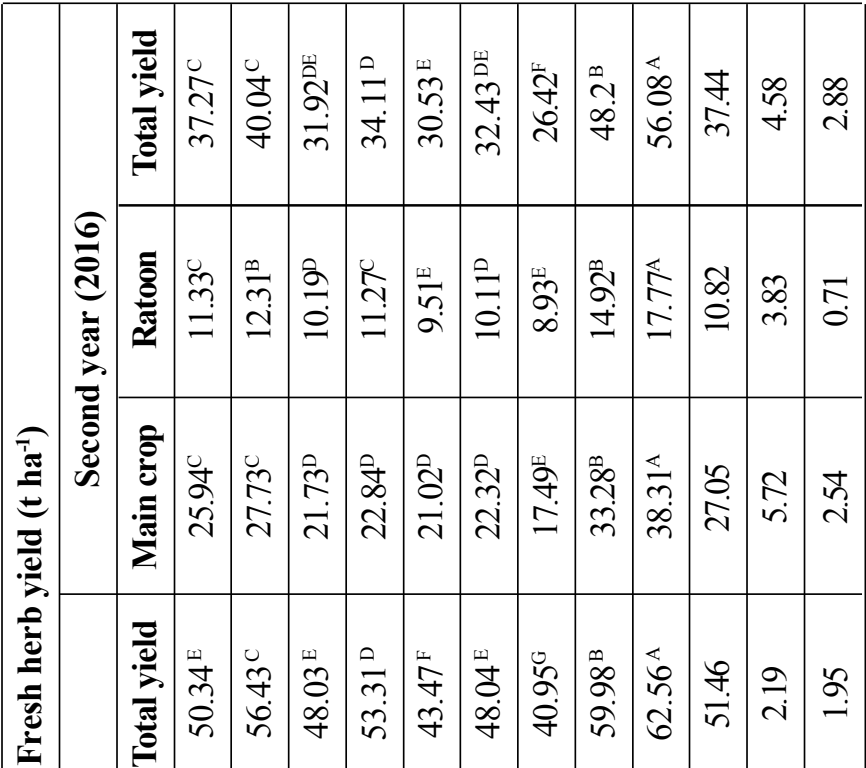

作

氙

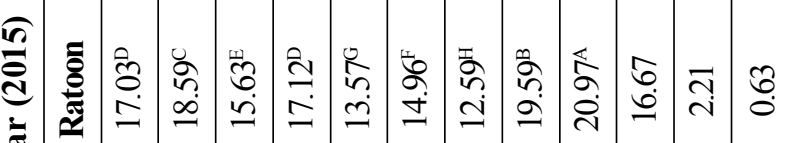

:

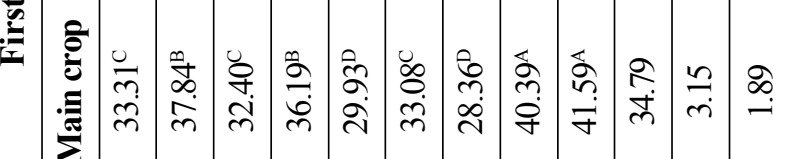

I

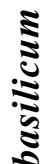

:

Iี

흐

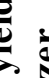

를

ธี.

这

$\ddot{\forall}$

产

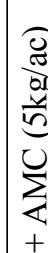

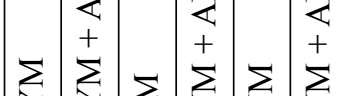

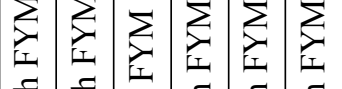

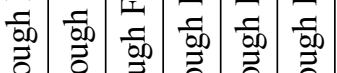

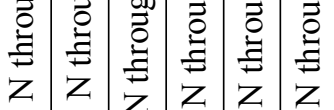

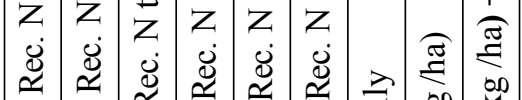

品

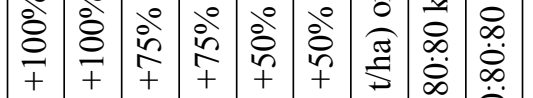

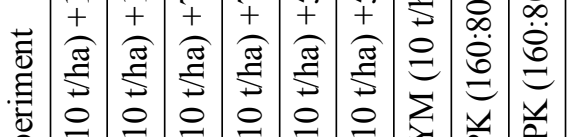

旁

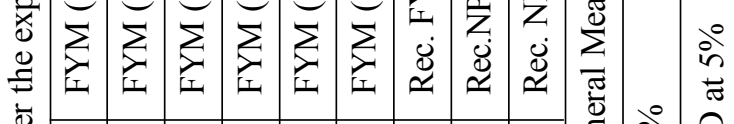

这 
Application of inorganic fertilizers are expected to release greater quantity of nutrients particularly $\mathrm{N}$, $\mathrm{P}, \mathrm{K}$ at a faster rate and higher level and there by greater uptake by the plants which resulted in higher growth and yield parameters. On the other hand application of FYM along with inorganic fertilizer release nutrients after mineralization. Such controlled but regulated supply of nutrients increased uptake $\mathrm{N}, \mathrm{P}, \mathrm{K}$ which in turn, brought about higher growth and yield. Increase in the yield parameters with combined use of organic and inorganic application reported in earlier reports of Joy et al. (2005) in black musli, Kothari et al. (2005) in Spilanthus acmella, Rajendran and Gnanavel (2008) in Aloe vera and Ravikumar et al. (2012) in coleus. Organic amendments show a slower nutrient release pattern than mineral fertilizer but facilitate an increased soil organic matter (SOM) content (Pinitpaitoon et al., 2011). Although Vanlauwe and Giller (2006) claim that organic resources are not sufficient enough to supply crops with the required nutrients, the increased SOM is enhancing productivity due to the improved soil properties (Watson et al., 2002). Similar results were obtained by Mohamad et al. (2014) and Asieh (2012).

\section{CONCLUSION}

The experimental results concluded that the conjunctive use of FYM (10 t/ha) $+100 \%$ recommended $\mathrm{N}$ through FYM + Arka Microbial Consortium@5kg/acre is found to have best microbial population dynamics and organic carbon content. However, the highest fresh herbage yield of sweet basil was recorded with integrated use of recommended FYM (10 t/ha) and recommended NPK (160:80:80 kg/ha). Further, the study evidently emphasis that the appropriate utilization of manures and bio-fertilizers within the nutrient management systems can enhance the soil microbial activity and diversity that reflected on yield sustainability.

\section{REFERENCES}

Alexander, M., 1977. Introduction to soil microbiology, 2nd edition, Krieger Publishing ompany, USA.

Al-Mansour Baraa , Kalaivanan D. and Suryanarayana M.A., 2019. Effects of organic and inorganic fertilizers on soil fertility, nutrient uptake and yield of French basil. Medicinal Plants - International Journal of Phytomedicines and Related Industries., 11(1):8-18.

Asieh, S., 2012. Studying the effects of chemical fertilizer and manure on growth rate and essence amount of (Ocimum basilicum L.). $J$. Eco. Environ., 18 (3): 517-520.

Bajracharya, R., 2011. Biological Characteristics of Soil. British Micro.Res.J., 1(1):11-25.

Baritaux, O., Richard, H., Touche, J. and Derbesy, M ., 1992. Effects of drying and storage of herbs and spices on the essential oil. Part I. Basil, Ocimum basilicum L. Flavour Fragr. J., 7: 267-271.

Bot, A. and Benites, J., 2005. The Importance of Soil Organic Matter: Key to Drought-Resistant Soil and sustained Food Production (Bulletin No. 5). Rome: Food and Agriculture Organization.

Ling, N., Sun, Y., Ma, J., Guo, J., Zhu, P., Peng, C., Yu, G., Ran, W., Guo, S., and Shen, Q. 2014. Response of the Bacterial Diversity and Soil Enzyme Activity in Particle-Size Fractions of Mollisol after Different Fertilization in a LongTerm Experiment. Biology and Fertility of Soils, 50 (6): 901-911.

Saviozzi, A., Levi-Minzi, R., Cardelli, R., and Riffaldi, R., 2001. A comparison of soil quality in adjacent cultivated, forest and native grassland soils. Plant and Soil, 233(2): 251-259.

Deforest, J. L., Smemo, K. A., Burke, D. J., Elliott, H. L. and Becker, J. C., 2012. Soil microbial responses to elevated phosphorus and $\mathrm{pH}$ in acidic temperate deciduous forests. Biogeochemistry, 109: 189:202.

Elliot, L.F. and Lynch, J.M., 1995. The international workshop on establishment of microbial inocula in soils: cooperative research project on biological resource management of the Organization for Economic Cooperation and 
Development (OECD). American Journal of Alternative Agriculture, 10: 50-73.

EL-tarabily, K.A. and Sivasithamparam, K., 2006. Non-streptomyceteactinomycetes as biocontrol agents of soil-borne fungal plant pathogens and as plant growth promoters. Soil Biology and Biochemistry, 38: 1505-1520.

Franchini, J.C., 2007. Microbiological parameters as indicators of soil quality under various soil management and crop rotation systems in southern Brazil. Soil Res., 92(1): 18-29.

Gundale, M. J., 2005. Restoration treatments in a Montana ponderosa pine forest: Effects on soil physical, chemical and biological properties. Forest Eco. Manag., 213 (1): 25-38.

Halvorson, A.D., Wienhold, B.J. and Black, A.L., 2002. Tillage, nitrogen, and cropping system effects on soil carbon sequestration. Soil Sci Soc Am J, 66: 906-912.

Jackson, M, L, 1973. Soil Chemical Analysis, Prentice Hall of India Pvt. Ltd., New Delhi, p. 498.

Joy, P.P., Savithri, K.E., Mathew, S., Thomas, J. and Kurien, K., 2005, Effect of sole and combined application of FYM and fertilizer on growth, yield and quality of black musli (Curculigo orchioides G.). J. Med. Aromat. Plant Sci., 27(3): 684-692.

Koopmans, C.J. and Smeding, F.W., 2008. A conceptual framework for soil management and its effect on soil biodiversity in organic and low input farming. 16th IFOAM organic world congress, cultivating the future based on science, Organic Crop Production, 1:66-69.

Kothari, S.K., Singh, C.P. and Kumar, Y., 2005, Growth and yield of Spilanthus acmella (Syn. Spilanthes mauritian) roots and its cultivation economics as influenced by Nitrogen and phosphorous application under semi and tropics. J. Med. Arom. Plants Sci., 27(2):283-286.

Krishnakumar, S., Saravanan, A., Natarajan, S.K., Veerabadran, V. and Mani, S., 2005, Microbial population and enzymatic activity as influenced by organic farming. Research J. Agri. Biol. Sciences, 1(1): 85-88.
Lalfakzuala, R., Kayang, H. and Dkhar, M. S., 2008. The effects of fertilizers on soil microbial components and chemical properties under leguminous cultivation. Am-Eurasian J. Agric. Environ. Sci., 3 (3): 314-324.

Lou, Y., Wang, J. and Liang, W., 2011. Impacts of 22year organic and inorganic $\mathrm{N}$ managements on soil organic $\mathrm{C}$ fractions in a maize field, northeast China. Catena, 87: 386-390.

Mbonigaba, M. J. J., 2007 . Etude de l'impact des composts a base de biomass vegetal sur ladyna mique des indicate urs physic chimiques, s et micro biologiques de la

fertilite des ols: Application sur trios sols acides tropicaux du Rwanda. Ph.D. Thesis, FUSAGx, Gembloux.

Mccarthy, A.J. and Williams, S.T., 1992. Actinomycetes as agents of biodegradation in the environment - a review. Gene. 115: 189-192.

Mishra, M.M. and Banger, K.C., 1985, Phosphocompost as a phosphorus source in neutral and alkaline soils. Soil Biology: Proc. Soil Biol. Symp. Eds. Mishra, M.M. and Kapoor, K.K., Haryana Agric. Univ. Hisar, India. P.139-147.

Mohammad, K., Mohsen, J. and Forough, D., 2014. The effects of organic and chemical fertilizers on yield and essential oil percentage of vegetative parts of (Ocimum basilicum L.). 59th International Congress and Annual Meeting of the Society for Medicinal Plant and Natural Product Research, p. 363-372

Palada M., Davis A., Crossman, C and Chichester, E. A., 2002. Sustainable crop management practices for improving production of culinary herbs in the Virgin Islands. In XXVI International Horticultural Congress: The Future for Medicinal and Aromatic Plants. 629: 289- 298.

Pansombat, K., Kanazawa, S. and Horiguchi, T., 1997. Microbial ecology in tea soils I. Soils properties and microbial populations. Soil Science and Plant Nutrition, 43: 317-327. 
Pinitpaitoon, S., Suwanarit, A. and Bell, R. W., 2011. A framework for determining the efficient combination of organic materials and mineral fertilizer applied in maize cropping. Field Crops Res., 124 (3): 302315.

Rajendran, A. and Gnanavel, I., 2008, Effect of organic manures and spacing on Aloe vera L. J. Med. Arom. Plants Sci, 30:40-42.

Ravikumar, M., Venkatesha, J., Niranjana, K. S. and Gurumurthy, B. R., 2012, Effect of Integrated Nutrient Management on Tuber Yield and Quality and Nutrient Uptake in Coleus forskohlii. J. Root Crops, 38 (2): 142-146.

Song, Y.N., Zhang, F.S., Marschner, P., Fan, F.L., Gao, H.M., Bao, X.G., Sun, J.H. and L.I., 2007. Effect of intercropping on crop yield and chemical and microbiological properties in rhizosphere of wheat (Triticum aestivum L.), maize (Zea mays L.), and faba bean (Vicia faba L.). Biology and Fertility of Soils, 43: 565- 574.

Su, Y.Z., Wang, F., Suo, D.R., Zhang, Z.H. and Du, M.W., 2006, Long-term effect of fertilizer and manure application on soil-carbon sequestration and soil fertility under the wheat-wheatmaize cropping system in northwest China. Nutr Cycl Agroecosyst, 75: 285-295. 35.

Vanlauwe, B. and Giller, K., 2006. Popular myths around soil fertility management in sub-Saharan Africa. Agri. Eco. Envi., 116(2): 34-46.

Vassilev, N., Massimmiliano, F. and Federico, F., 1996. Rock phosphate solubilization with gluconic acid produced by immobilized Penicillium variable P16. Biotech. Tech., 10: 585-88.
Venkateswarlu, B. and Srinivasa Rao, C.H., 2000. Soil microbial diversity and the impact of agricultural practices. Central Research Institute for Dryland Agriculture, Santoshnagar, India.

Wang, W., Niu, J., Zhou, X. and Wang, Y., 2011. Long-term change in land management from subtropical wetland to paddy field shifts soil microbial community structure as determined by PLFA and T-RFLP. Pol $J$ Eco., 59: 37-44.

Watson, C. A., Atkinson, D., Gosling, P., Jackson, L. R. and Rayns, F. W., 2002. Managing soil fertility in organic farming systems. Soil Use Manag., 18: 239-24.

Watts, D. B., Allen, T. H., Feng, Y. and Prior, S. A., 2010, Soil microbial community dynamics as influenced by composted dairy manure, soil properties, and landscape position. Soil Science, 175: 474-486.

Yang, X., Li, P., Zhang, S., Sun, B. and Xinping, C., 2011, Long-term-fertilization effects on soil organic carbon, physical properties, and wheat yield of a loess soil. J. Plant Nutri. Soil Sci., 174 (5): 775-784.

Yu, H., Ding, W., Luo, J., Geng, R. and Cai, Z., 2012, Long-term application of organic manure and mineral fertilizers on aggregation and aggregate-associated carbon in a sandy loam soil. Soil Tillage Res., 124(1):170-177.

Zeinab, S., 2005, Physiological Studies on Basil Plant. (Ph.D.Thesis) submitted to the graduate division of the University of almansoura, Cairo.

(Received on 7.09.2020; Revised on 15.05.2021; Accepted on 13.06.2021) 